\title{
PENINGKATAN KOMPETENSI GURU MENERAPKAN TEKNOLOGI INFORMASI DAN KOMUNIKASI (TIK) DALAM PROSES PEMBELAJARAN MELALUI SUPERVISI AKADEMIK DI TK NEGERI PEMBINA I KOTA JAMBI
}

\author{
Letti Eliyani \\ TK Negeri Pembina I \\ Email letti3377@gmail.com
}

Penelitian ini bertujuan untuk mengetahui (a) Peningkatan Kompetensi Guru Menerapkan TIK Dalam Proses Pembelajaran Melalui Supervisi Akademik dan (b) aktivitas guru kelas dalam menggunakan media tekhnologi komunikasi informasi, digunakan metode penelitian tindakan sekolah (PTS) dengan dua siklus yang masing-masing siklusnya terdiri dari tahap (1) perencanaan, (2) pelaksanaan tindakan perbaikan, (3) observasi, dan (4) refleksi.

Hasil penelitian menunjukkan bahwa (a) terjadi peningkatan kompetensi guru dalam menerapkan TIK Melalui Supervisi Akademik Pada Guru TK Negeri Pembina I Kota Jambi. Penilaian melalui Rubrik Penilaian Rencana Pelaksanaan Pembelajaran pada siklus 1 yang mencapai nilai 119, berada pada katagori baik, dan hasil penilaian pada siklus kedua yang mencapai nilai 151, berada pada kategori sangat baik, dan (b) aktivitas guru dalam pelaksanaan pembelajaran pada siklus kedua lebih baik dari pada siklus satu. Penilaian melalui Rubrik Penilaian Aktivitas Guru dalam proses pembelajaran selama siklus satu mencapai nilai 30 atau tergolong baik, dan pada siklus kedua mencapai nilai 36, yang berarti tergolong sangat baik. Di mana hasil akhir yang diperoleh dari Siklus I skor 155 dan Siklus II skor 195 dalam penelitian ini dengan prosentase naik 25,8 \%.

Kata Kunci: Kompetensi Guru, TIK, Supervisi Akademik

\section{A. PENDAHULUAN}

\section{Latar Belakang Masalah}

Perubahan lingkungan luar dunia pendidikan, mulai lingkungan sosial, ekonomi, teknologi, sampai politik mengharuskan dunia pendidikan memikirkan kembali bagaimana perubahan tersebut mempengaruhinya sebagai sebuah institusi sosial dan bagaimana harus berinteraksi dengan perubahan tersebut. Salah satu perubahan lingkungan yang sangat mempengaruhi dunia pendidikan adalah hadirnya Teknologi, Informasi dan Komunikasi (TIK).

Dalam menyoroti salah satu peran guru dalam proses pembelajaran, yaitu sebagai perencana pembelajaran, setiap guru pada satuan pendidikan, termasuk 
guru TK berupaya meningkatkan kompetensi TIK agar pembelajaran efektif dan bermutu. Pembelajaran yang berlangsung secara efektif dan bermutu akan berimplikasi pada peningkatan mutu proses dan hasil belajar peserta didik. Guru taman kanak-kanak Negeri Pembina I telah melaksanakan proses belajar mengajar dengan didukung TIK. Namun masih ditemukan berbagai kekurangan baik menyangkut persiapan maupun dalam pelaksanaan proses belajar mengajar, sebagai berikut:

1. Sebelum penyusunan RPP

a. Sebagian besar guru tidak menentukan kriteria ketuntasan minimal KKM.

b. Sebagian guru tidak membuat sendiri silabus mata pelajaran.

2. Dalam Penyusunan RPP:

a. Sebagian besar guru kurang menjelaskan apa yang dilakukan siswa selama berlangsungnya pembelajaran dalam rencana kegiatan pembelajarannya.

b. Sebagian besar guru tidak menjelaskan sumber belajar dengan rinci.

c. Sebagian besar guru tidak menjelaskan (1) bentuk instrumen evaluasi, (2) format/lembaran evaluasi atau butir soal (free test dan post test), (3) pedoman penilaian, dan kunci jawaban, dalam evaluasi proses dan hasil belajar siswa.

d. Sebagian besar guru tidak merencanakan tindak lanjut setelah selesai pembelajaran (pembelajaran remedial, program pengayaan, layanan konseling atau tugas individu / kelompok) dalam kaitan antara KKM mata pelajaran dengan nilai yang dicapai siswa.

3. Pelaksanaan pembelajaran :

a. Sebagian besar guru tidak berpedoman sepenuhnya pada RPP dalam pelaksanan pembelajarannya.

b. Semua itu terkait dengan kondisi di lapangan bahwa : (a) Semua guru kelas tidak berlatar belakang pendidikan TIK, (b) banyaknya guru kelas yang hanya kompeten dalam cabang pelajaran tertentu yang bukan TIK, (c) tidak semua guru kelas, terutama yang berstatus honorer, berkesempatan mengikuti penataran atau diklat TIK, (d) jarangnya kegiatan KKG TIK yang khusus membahas TIK tersebut. 
Kondisi yang demikian menjadikan persepsi guru kelas mengenai ICT yang harus dikuasai sebelum melaksanakan pembelajaran di kelas, studio atau tempat belajar lainnya menjadi kurang dikuasai. Misalnya masih terdapat guru yang belum memahami operasi komputer dan infokus, apalagi mengenai Internet. Hal ini tentu akan menghambat upaya peningkatan mutu proses dan hasil pembelajaran Guru, karena kompetensi-nya tidak dikuasai dengan baik. Padahal, keberhasilan sebuah kegiatan, lebih dari 50\% ditentukan oleh kompetensi yang baik, sehingga keberhasilan pembelajaran pun ditentukan oleh kompetensi guru.

Dengan memahami kondisi yang demikian, maka dipandang perlu adanya Peningkatan Kompetensi Guru Menerapkan TIK Dalam Proses Pembelajaran Melalui Supervisi Akademik di TK Negeri Pembina 1 Kota Jambi.

\section{Rumusan Masalah}

Rumusan masalah dalam penelitian ini adalah: apakah supervisi akademik bisa meningkatkan kompetensi guru dalam menerapkan TIK dalam proses pembelajaran?

\section{Tujuan Penelitian}

Untuk Mengetahui dan Menganalisis Apakah Supervisi Akademik Bisa Meningkatkan Kompetensi Guru Dalam Menerapkan TIK Dalam Proses Pembelajaran.

\section{Manfaat Penelitian}

Penelitian tindakan sekolah ini diharapkan dapat bermanfaat:

\section{Bagi Siswa}

Agar siswa lebih aktif dan kreatif dalam proses pembelajaran.

\section{Bagi Guru}

- Meningkatkan kompetensi guru dalam bidang TIK

- Memberikan motivasi kepada guru untuk terus mengembangkan kemampuan terutama yang berhubungan dengan proses pembelajaran dan penggunaan media. 


\section{B. KAJIAN TEORI}

\section{Kompetensi Guru}

\section{a. Pengertian Kompetensi Guru}

Kompetensi dalam Bahasa Inggris disebut competency, merupakan kebulatan penguasaan pengetahuan, ketrampilan, dan sikap yang ditampilkan melalui unjuk kerja yang dicapai setelah menyelesaikan suatu program pendidikan. ${ }^{1}$ Pengertian dasar kompetensi (competency) yaitu kemampuan atau kecakapan. $^{2}$

Menurut Echols dan Shadly "Kompetensi adalah kumpulan pengetahuan, perilaku, dan keterampilan yang harus dimiliki guru untuk mencapai tujuan pembelajaran dan pendidikan. Kompetensi diperoleh melalui pendidikan, pelatihan, dan belajar mandiri dengan memanfaatkan sumber belajar". ${ }^{3}$

Kompetensi pada dasarnya merupakan deskripsi tentang apa yang dapat dilakukan seseorang dalam bekerja, serta apa wujud dari pekerjaan tersebut yang dapat terlihat. Untuk dapat melakukan suatu pekerjaan, seseorang harus memiliki kemampuan dalam bentuk pengetahuan, sikap dan ketrampilan yang relevan dengan bidang pekerjaannya. ${ }^{4}$ Seseorang disebut kompeten dalam bidangnya jika pengetahuan, ketrampilan dan sikapnya, serta hasil kerjanya sesuai standar (ukuran) yang ditetapkan dan/atau diakui oleh lembanganya/pemerintah. ${ }^{5}$

Dalam Undang-undang Republik Indonesia Nomor 14 Tahun 2005 tentang Guru dan Dosen, dijelaskan bahwa: "kompetensi adalah seperangkat pengetahuan, keterampilan, dan perilaku yang harus dimiliki, dihayati, dan dikuasai oleh guru atau dosen dalam melaksanakan tugas keprofesionalan". 6

\footnotetext{
1 J.B Situmorang dan Winarno, Pendidikan Profesi dan Sertifikasi Pendidik, (Klaten: Macanan Jaya Cemerlang, 2008), hal. 17

2 Jamil Suprihatiningkrum, Guru Profesional : Pedoman Kinerja, Kualifikasi \& Kompetensi Guru, (Yogyakarta: Ar-Ruzz Media, 2014), hal. 97

${ }^{3}$ Jejen Musfah, Peningkatan Kompetensi Guru : Melalaui Pelatihan dan Sumber Belajar Teori dan Praktik, (Jakarta: Kencana, 2012), hal. 27

${ }^{4}$ Suyanto dan Asep Jihad, Menjadi Guru Profesional: Strategi Meningkatkan Kualifikasi dan Kualitas Guru di Era Globalisasi, (Jakarta: Erlangga, 2013), hal. 39

${ }^{5}$ Jejen Musfah, Op.Cit, hal. 28

${ }^{6}$ E. Mulyasa, Standar Kompetensi dan Sertifikasi Guru, (Bandung: PT Remaja Rosdakarya, 2013), hal. 25
} 
Berdasarkan beberapa pendapat tersebut dapat disimpulkan bahwa pengertian kompetensi guru adalah pengetahuan, keterampilan dan kemampuan yang sebaiknya dapat dilakukan seorang guru dalam melaksanakan pekerjaannya Menurut Mulyasa, pada hakekatnya standar kompetensi guru adalah untuk mendapatkan guru yang baik dan profesional, yang memiliki kompetensi untuk melaksanakan fungsi dan tujuan sekolah khususnya, serta tujuan pendidikan pada umumnya, sesuai kebutuhan masyarakat dan tuntutan zaman. ${ }^{7}$

Berdasarkan penjelasan di atas guru dituntut untuk profesional dalam menjalankan perannya sebagai pengajar dimana guru harus bisa menyesuaikan apa yang dibutuhkan masyarakat dan jaman dalam hal ini yaitu kemajuan ilmu pengetahuan dan teknologi yang terus berkembang. Stephen P. Becker dan Jack Gordon mengemukakan beberapa unsur atau elemen yang terkandung dalam konsep kompetensi, yaitu: ${ }^{8}$

1) Pengetahuan (knowledge), yaitu kesadaran di bidang kognitif. Misalnya, seorang guru mengetahui cara melaksanakan kegiatan identifikasi, penyuluhan, dan proses pembelajaran terhadap warga belajar.

2) Pengertian (understanding), yaitu kedalaman kognitif dan efektif yang dimiliki siswa. Misalnya, seorang guru yang akan melaksanakan kegiatan harus memiliki pemahaman yang baik tentang keadaan dan kondisi warga belajar di lapangan, sehingga dapat melaksanakan program kegiatan secara baik dan efektif.

3) Keterampilan (skill), yaitu kemampuan individu untuk melakukan suatu tugas atau pekerjaan yang dibebankan kepadanya. Misalnya, kemampuan yang dimiliki oleh guru untuk menyusun alat peraga pendidikan secara sederhana.

4) Nilai (value), yaitu suatu norma yang telah diyakini atau secara psikologis telah menyatu dalam diri individu.

5) Minat (interest), yaitu keadaan yang mendasari motivasi individu, keinginan yang berkelanjutan, dan orientasi psikologis. Misalnya, guru yang baik selalu

\footnotetext{
${ }^{7}$ Ibid, hal. 17

${ }^{8}$ Bernawi Munthe, Desain Pembelajaran, (Yogyakarta: Pustaka Insan Madani, 2009), hal. 29
} 
tertarik kepada warga belajar dalam hal membina dan memotivasi mereka supaya dapat belajar sebagaimana yang diharapkan.

\section{b. Jenis-jenis Kompetensi Guru}

Menurut Charles dalam Mulyasa mengemukakan bahwa: competency as rational performance which satisfactorily meets the objective for a desired condition (kompetensi merupakan perilaku yang rasional unstuck mencapai tujuan yang dipersyaratkan sesuai dengan kondisi yang diharapkan). Kompetensi yang harus dikuasai dan diterapkan oleh guru profesional dalam membelajarkan siswa atau peserta didik di kelas menurut Sudjana ialah mencakup: menguasai bahan atau materi pelajaran, mengelola program belajar mengajar, mengelola kelas, menggunakan media atau sumber belajar, menguasai landasan pendidikan, mengelola interaksi belajar mengajar, menilai prestasi belajar siswa, mengenal fungsi dan layanan bimbingan dan konseling, mengenal dan menyelenggarakan administrasi sekolah, serta memahami dan menafsirkan hasil penelitian guna keperluan pengajaran. ${ }^{9}$

Sedangkan dalam Undang-undang Guru dan Dosen No.14/2005 Pasal 10 ayat 1 Dan Peraturan Pemerintah No.19/2005 pasal 28 ayat 3 yang dikuti Jamil dalam bukunya dinyatakan bahwa kompetensi guru meliputi kompetensi pedagogik, kompetensi kepribadian, kompetensi sosial dan kompetensi professional:

1) Kompetensi Pedagogik

Kompetensi pedagogik merupakan kemampuan teknis dalam menjalankan tugas sebagai pendidik, pengajar dan pembimbing. Kompetensi pedagogik merupakan kemampuan guru yang berkenaan dengan pemahaman terhadap peserta didik dan pengelolaan pembelajaran yang mendidik dan dialogis. Secara substantif, kompetensi ini mencakup kemampuan pemahaman terhadap peserta didik, perancangan dan pelaksanaan pembelajaran, evaluasi hasil belajar, serta pengembangan peserta didik untuk mengaktualisasikan berbagai potensi yang dimilikinya.

\footnotetext{
${ }^{9}$ Abdul Hadis dan Nurhayati, Manajemen Mutu Pendidikan, (Bandung: Alfabeta, 2012), hal.19-20
} 
Lebih lanjut dalam Permendiknas No.16 Tahun 2007 tentang Standar Pendidik dan Kependidikan dikemukakan bahwa kompetensi pedagogik merupakan kemampuan guru dalam pengelolaan pembelajaran siswa yang sekurang-kurangnya meliputi hal-hal sebagai berikut:

a) Pemahaman wawasan atau landasan kependidikan (kemampuan mengelola pembelajaran)

b) Pemahaman terhadap peserta didik

c) Perancangan pembelajaran

d) Pelaksanaan pembelajaran yang mendidik dan dialogis

e) Pemanfaatan teknologi pembelajaran

f) Evaluasi hasil belajar

g) Pengembangan peserta didik untuk mengaktualisasikan berbagai potensi yang dimilikinya.

2) Kompetensi Kepribadian

Kompetensi kepribadian merupakan kemampuan personal yang mencerminkan kepribadian yang mantap, stabil, dewasa, arif dan wibawa, menjadi teladan bagi peserta didik, dan berakhlak mulia. Kepribadian guru sangat kuat pengaruhnya terhadap tugasnya sebagai pendidik. Kewibawaan guru ada dalam kepribadiannya. Sulit bagi guru mendidik peserta didik untuk disiplin kalau guru yang bersangkutan tidak disiplin. Peserta didik akan menggugu dan meniru gurunya sehingga apa yang dikatakan oleh guru seharusnya sama dengan tindakannya. Guru yang jujur dan tulus dalam menjalankan tugasnya sebagai pendidik berbeda dengan guru yang mengajar karena tidak ada pekerjaan lain. Peserta didik dengan mudah membaca hal tersebut.

3) Kompetensi Sosial

Kompetensi sosial berkenaan dengan kemampuan pendidik sebagai bagian dari masyarakat untuk berkomunikasi dan bergaul secara efektif dengan peserta didik, sesama pendidik, tenaga kependidikan, orang tua/wali peserta didik, dan masyarakat sekitar. Selanjutnya pengertian lain, terdapat kriteria lain kompetensi yang harus dimiliki oleh setiap guru. 
Guru merupakan makhluk sosial, yang dalam kehidupannya tidak bisa terlepas dari kehidupan sosial masyarakat dan lingkungannya. Oleh karena itu guru dituntut memiliki kompetensi sosial memadai, terutama dalam kaitannya dengan pendidikan, yang tidak terbatas pada pembelajaran di sekolah tetapi juga pendidikan yang terjadi dan berlangsung di masyarakat. dengan demikian guru diharapkan dapat memfungsikan dirinya sebagai makhluk sosial di masyarakat dan lingkungannya, sehingga mampu berkomunikasi dan bergaul secara efektif dengan peserta didik, sesama pendidik, tenaga kependidikan, orang tua dan wali peserta didik serta masyarakat sekitar.

4) Kompetensi Profesional

Kompetensi profesional merupakan kemampuan yang berkenaan dengan penguasaan materi pembelajaran bidang studi secara luas dan mendalam, yang mencakup penguasaan substansi isi materi kurikulum mata pelajaran di sekolah dan substansi keilmuan yang menaungi materi kurikulum tersebut, serta menambah wawasan keilmuan sebagai guru.

Dari standar kompetensi di atas dapat disimpulkan bahwa guru harus memiliki kemampuan untuk menguasai kompetensi pedagogik, kepribadian, sosial dan kompetensi profesional.

\section{Tenologi Informasi}

\section{a. Pengertian Teknologi Informasi}

Menurut Bambang Warsita (teknologi informasi adalah sarana dan prasarana (hardware, software, useware) sistem dan metode untuk memperoleh, mengirimkan, mengolah, menafsirkan, menyimpan, mengorganisasikan, dan menggunakan data secara bermakna. ${ }^{10}$ Hal yang sama juga di ungkapkan oleh Lantip dan Rianto teknologi informasi diartikan sebagai ilmu pengetahuan dalam bidang informasi yang berbasis komputer dan perkembanganya sangat pesat. ${ }^{11}$

Hamzah B. Uno dan Nina Lamatenggo juga mengemukakan teknologi informasi adalah suatu teknologi yang digunakan untuk mengolah data. Pengolahan itu termasuk memproses, mendapatkan, menyusun, menyimpan,

\footnotetext{
${ }^{10}$ Bambang Warsita, Teknologi Pembelajaran: Landasan \&Aplikasinya, (Jakarta: Rineka Cipta, 2008), hal. 135.

${ }^{11}$ Lantip, Riyanto, Teknologi Informasi Pendidikan (Yogyakarta: Gava Media, 2011), hal. 4
} 
memanipulasi data dalam berbagai cara untuk menghasilkan informasi yang berkualitas, yaitu informasi yang relevan, akurat, dan tepat waktu. ${ }^{12}$

Menurut McKeown dalam Suyanto, Teknologi Informasi dan Komunikasi (TIK) merujuk pada seluruh bentuk teknologi yang digunakan untuk menciptakan, menyimpan, mengubah, dan menggunakan informasi dalam segala bentuknya. ${ }^{13}$ Teori yang lain juga diungkapkan oleh Williams dalam Suyanto teknologi informasi merupakan sebuah bentuk umum yang menggambarkan setiap teknologi yang membantu menghasilkan, memanipulasi, menyimpan, mengkomunikasikan, dan atau menyampaikan informasi. ${ }^{14}$

Dari beberapa pendapat para ahli di atas dapat disimpulkan bahwa Teknologi Informasi dan Komunikasi (TIK) adalah suatu teknologi berupa (hardware, software, useware) yang digunakan untuk memperoleh, mengirimkan, mengolah, menafsirkan, menyimpan, mengorganisasikan, dan menggunakan data secara bermakna untuk memperoleh informasi yang berkualitas dan juga untuk menyampaikan informasi.

\section{b. Manfaat Teknologi Informasi}

Menurut Abdulhak terdapat klasifikasi pemanfaatan Teknologi Informasi dan Komunikasi (TIK) ke dalam tiga jenis, yaitu: Pertama, Teknologi informasi dan komunikasi (TIK) sebagai media atau alat bantu pendidikan yaitu hanya sebagai pelengkap untuk memperjelas uraian-uraian yang disampaikan. Kedua, ICT sebagai sumber yakni sebagai sumber informasi dan mencari informasi. Ketiga, ICT sebagai sistem pembelajaran. ${ }^{15}$

Menurut Bambang Warsita, ${ }^{16}$ secara umum ada tiga pemanfaatan Teknologi Informasi dan Komunikasi (TIK) atau instruksional komputer dan internet untuk pendidikan dan pembelajaran, yaitu:

\footnotetext{
12 Hamzah B. Uno, Nina Lamatenggo, Teknologi. Komunikasi dan Informasi Pembelajaran. (Jakarta: Bumi Aksara, 2011), hal. 57.

${ }^{13}$ Suyanto, Pengantar Teknologi Informasi Untuk Bisnis. (Yogyakarta: Penerbit Andi, 2005), hal. 10.

${ }^{14}$ Ibid

15 Abdulhak, Ishak dan Deni Darmawan, Teknologi Pendidikan, (Bandung : PT Remaja Rosdakarya, 2013), hal. 413.

${ }^{16}$ Bambang Warsita, Op. Cit, hal. 150-151
} 
Pertama, Learning about computers and the internet, yaitu Komputer dapat dijadikan sebagai objek pembelajaran, misalnya ilmu computer (computer science).

Kedua, Learning with computers and the internet, yaitu teknologi informasi memfasilitasi pembelajaran sesuai dengan kurikulum yang berlaku di sekolah. Misalnya Pustekkom, Depdiknas mengembangkan progam CD multimedia interaktif untuk mata pelajaran.

Dapat disimpulkan bahwa manfaat Teknologi Informasi Dan Komunikasi (TIK) adalah sebagai berikut: Pertama, TIK sebagai sumber yakni TIK dapat dimanfaatkan untuk sumber informasi dan untuk mencari informasi yang akan dibutuhkan. Kedua, TIK sebagai media, sebagai alat bantu yang memfasilitasi penyampaian suatu informasi agar dapat diterima dan dimengerti dengan mudah. Ketiga, TIK sebagai pengembang keterampilan pembelajaran, pengembangan keterampilan-keterampilan berbasis teknologi informasi dengan aplikasi-aplikasi dalam kurikulum.

\section{c. Teknologi Informasi dan Komunikasi Pendidikan}

Teknologi informasi dan komunikasi pendidikan mengandung dua unsur yang saling terkait yaitu teknologi informasi pendidikan dan teknologi komunikasi pendidikan. Nasution mengemukakan bahwa pada hakikatnya teknologi pendidikan adalah suatu pendekatan yang sistematis dan kritis tentang pendidikan. $^{17}$

Teknologi pendidikan memandang soal mengajar dan belajar sebagai masalah atau problema yang harus dihadapi secara rasional dan ilmiah. Teknologi pendidikan merupakan pengembangan, penerapan, dan penilaian sistem-sistem, teknik dan alat bantu untuk memperbaiki dan meningkatkan proses belajar manusia. Dalam pengertian ini lebih diutamakan tentang proses belajar itu sendiri dibandingkan dengan alat-alat yang dapat membantu proses belajarnya. Oleh karena itu dapat dikatakan bahwa teknologi pendidikan itu mengenai software dan hardwarenya, software antara lain menganalisis dan mendesain urutan atau

${ }^{17}$ Nasution. Teknologi Pendidikan. (Jakarta: Bumi Aksara, 2011), hal. 1-3 
langkah-langkah belajar berdasarkan tujuan yang ingin dicapai dengan metode penyajian yang serasi serta penilaian keberhasilannya.

Pendapat lain dikemukakan oleh Sudarwan Danim, ${ }^{18}$ yang mengungkapkan bahwa teknologi pendidikan diartikan sebagai media yang lahir dari revolusi teknologi komunikasi yang dapat digunakan untuk tujuan-tujuan pengajaran di samping guru, buku, dan papan tulis. Teknologi pendidikan memiliki syarat yaitu: prosedur, ide, peralatan dan organisasi yang dikaji secara sistematis, logis dan ilmiah. Oleh karena itu dapat dikatakan bahwa sebenarnya media teknologi tertentu tidak secara khusus dibuat untuk teknologi pendidikan, melainkan teknologi pendidikan berupa media teknologi yang dimanfaatkan untuk tujuantujuan pendidikan, kecuali mesin mengajar, sebenarnya modifikasi pemanfaatan komputer dan pengajaran berprogram.

Yusufhadi Miarso (Sudarwan Danim), mengemukakan bahwa teknologi komunikasi pendidikan adalah sebuah spesifikasi dalam bidang teknologi pendidikan, yaitu yang lebih banyak merupakan prinsip dan konsep ilmu komunikasi, serta lebih memperhatikan penggunaan sumber belajar berupa media komunikasi masa dan elektronik. ${ }^{19}$

Dari pengertian tersebut dapat diketahui bahwa teknologi komunikasi pendidikan adalah teknologi komunikasi untuk pendidikan. Teknologi komunikasi untuk pendidikan merupakan penerapan praktis dari ilmu pengetahuan tentang tingkah laku, ilmu komunikasi, dan ilmu manajemen. Pada dasarnya teknologi pendidikan banyak memanfaatkan jasa media teknologi yang ada dalam kehidupan sehari-hari. Teknologi komunikasi yang dimanfaatkan untuk tujuantujuan pendidikan atau yang sengaja dirancang itu disebut teknologi komunikasi pendidikan.

\section{Supervisi Akademik}

Secara bahasa supervisi berarti mengamati, mengawasi, atau membimbing kegiatan-kegiatan yang dilakukan oleh orang lain dengan maksud untuk

\footnotetext{
${ }^{18}$ Sudarwan Danim, 1994, hal. 7

${ }^{19}$ Ibid, hal. 8
} 
mengadakan perbaikan. Supervisi berasal dari kata "super" artinya lebih atau atas, dan "vision" artinya melihat atau meninjau. Secara estimologi supervisi artinya melihat atau meninjau yang dilakukan oleh atasan terhadap pelaksanaan kegiatan bawahannya. $^{20}$ Menurut Ngalim Purwanto, supervisi adalah suatu aktivitas pembinaan yang direncanakan untuk membantu para guru dan pegawai sekolah lainnya dalam melakukan pekerjaan mereka secara efektif. ${ }^{21}$

Menurut Sergiovani dan Starrat, supervisi merupakan suatu proses yang dirancang secara khusus untuk membantu para guru dan supervisor dalam mempelajari tugas sehari-hari di sekolah; agar dapat menggunakan pengetahuan dan kemampuannya untuk memberikan layanan yang lebih baik pada orang tua peserta didik dan sekolah, serta berupaya menjadikan sekolah sebagai masyarakat belajar yang lebih efektif". 22

Konsep supervisi didasarkan atas keyakinan bahwa perbaikan merupakan suatu usaha yang kooperatif dari semua orang yang berpartisipasi dan supervisor yang bertindak sebagai stimulator, pembimbing, dan konsultan bagi para tenaga pendidik dalam rangka upaya perbaikan. Supervisi yang dilakukan oleh pengawas satuan pendidikan, tentu memiliki misi yang berbeda dengan supervisi oleh kepala sekolah. Dalam hal ini supervisi lebih ditujukan untuk memberikan pelayanan kepada kepala sekolah dalam melakukan pengelolaan kelembagaan secara efektif dan efesien serta mengembangkan mutu kelembagaan pendidikan.

Menurut Suharsimi Arikunto dalam bukunya yang berjudul dasar-dasar supervisi akademik adalah supervisi yang menitikberatkan pengamatan pada masalah akademik, yaitu yang langsung berada dalam lingkup kegiatan pembelajaran yang dilakukan oleh guru untuk membantu siswa ketika sedang dalam proses belajar. $^{23}$ Menurut Glickman, supervisi akademik adalah

\footnotetext{
${ }^{20}$ Mukhtar dan Iskandar, Orientasi Baru Supervisi Pendidikan, (Jakarta: Gaung Persada Press, 2009), Cet. Ke1, h.41

${ }^{21}$ Ngalim Purwanto, Administrasi dan Supervisi Pendidikan, (Bandung: PT Remaja Rosadakarya, 2005), Cet. Ke-15, h. 76

${ }^{22}$ Mulyasa, Menjadi Kepala Sekolah Professional, (Bandung: PT. Remaja Rosdakarya, 2004), Cet. Ke-3, h. 111

${ }^{23}$ Suharsimi Arikunto, Dasar-dasar Supervisi, (Jakarta: Rineka Cipta, 2004), Cet. I, h. 5
} 
serangkaian kegiatan membantu guru mengembangkan kemampuannya mengelola proses pembelajaran demi pencapaian tujuan pembelajaran. ${ }^{24}$

Sedangkan menurut Daresh bahwa supervisi akademik merupakan upaya membantu guru-guru mengembangkan kemampuannya mencapai tujuan pembelajaran. Jadi supervisi akademik tidak sama sekali menilai unjuk kerja guru dalam mengelola proses pembelajaran, melainkan membantu guru mengembangkan kemampuan profesionalnya.

\section{METODE PENELITIAN}

\section{Setting Penelitian}

Penelitian Tindakan Sekolah (PTS) ini dilaksanakan di TK Negeri 1 Pembina Kota Jambi yang beralamatkan di Jln Letmud Sani Bandung RT 06 Kel. Sungai Putri Kec. Danau Sipin kota Jambi. Alasan pemilihan lokasi karena peneliti adalah kepala sekolah di TK tersebut. Dengan demikian akan memperlancar pelaksanaan penelitian.

\section{Subjek Penelitian}

Subyek penelitian ini adalah Guru Kelas TK Negeri Pembina I yang berjumlah 2 orang. Metode yang digunakan dalam penelitian ini adalah metode Penelitian Tindakan Sekolah (PTS). Masalah nyata yang ditemukan di sekolah, khususnya pada guru kelas adalah belum optimalnya dalam menyusun RPP walaupun dari segi implementasi menggunakan TIK.

\section{Prosedur Penelitian}

Prosedur penelitian menggunakan siklus dengan beberapa tahap yaitu: (1) perencanaan, (2) pelaksanaan, (3) observasi dan (4) refleksi.

\section{Instrumen Penelitian}

Dalam penelitian ini instrumen yang digunakan untuk mengumpulkan data adalah lembar observasi berupa rubric, Wawancara, Studi Dokumenter dan Studi Pustaka. Rubrik ini diisi oleh peneliti melalui pengamatan sebelum, pada

24 Direktorat Tenaga Kependidikan, Dirjen Peningkatan Mutu Pendidikan dan Tenaga Kependidikan. Depdiknas. Metode dan Tekhnik Supervisi. Jakarta. 2008, h. 1 
saat, dan sesudah proses penyusunan RPP. Hasilnya digunakan untuk menentukan tindakan selanjutnya.

\section{HASIL PENELITIAN DAN PEMBAHASAN}

Sebelum melakukan tindakan perbaikan, peneliti terlebih dahulu melakukan kegiatan orientasi sebagai studi pendahuluan. Dalam kegiatan ini guru "didiagnosis" sehingga peneliti menemukan derajat kelengkapan dan kesistematisan RPP yang disusun guru pada saat awal kegiatan mengajar. Peneliti mengamati aktivitas guru dalam persiapan dan selama proses penyusunan RPP, kemudian mengevaluasi RPP yang dibuatnya.

Hasil pengamatan dan evalusi tersebut kemudian dijadikan bahan untuk mencari upaya perbaikan (tahap tindakan) pada siklus penelitian. Prakteknya, guru-guru diminta menyusun secara spontan tanpa ada intervensi atau berlangsung alami seperti yang mereka lakukan sehari-hari sebelum mengajar. Dengan menggunakan Rubrik Penilaian Aktivitas Guru Kelas Dalam Peningkatan Kompetensi Guru Menerapkan TIK dalam proses Pembelajaran Melalui Supervisi Akademik.

Tabel 1. Rekapitulasi pada Rubrik Skor Kemampuan Guru Siklus 1

\begin{tabular}{|l|c|c|c|c|}
\hline \multirow{2}{*}{ No } & Nama Guru & \multicolumn{3}{|c|}{ Skor Penilaian } \\
\cline { 3 - 5 } & & $\begin{array}{c}\text { Persiapan } \\
\text { Penyusunan RPP }\end{array}$ & $\begin{array}{c}\text { Aktivitas Guru Dalam } \\
\text { Proses Pembelajaran }\end{array}$ & $\begin{array}{c}\text { Penilaian } \\
\text { Rpp }\end{array}$ \\
\hline 1 & A & 5 & 29 & 110 \\
\hline 2 & B & 7 & 31 & 128 \\
\hline \multicolumn{2}{|c|}{ Jumlah } & 12 & 60 & 119 \\
\hline
\end{tabular}

Dari Tabel 1 dapat dilihat, tentang aktivitas guru kelas, proses penyusunan RPP, proses pembelajaran dan penilaian RPP setelah di implementasikan pada Siklus 1 adalah sebagai berikut untuk persiapan penyusunan RPP pada Siklus 1 
mencapai nilai 6 rencana pelaksanaan pembelajaran pada siklus 1 yang mencapai nilai 119, berada pada kategori baik, penilaian melalui rubrik penilaian aktivitas guru dalam proses pembelajaran selama pada siklus kesatu yang mencapai nilai 30 atau tergolong baik.

Tabel 2. Rekapitulasi pada Rubrik Skor Kemampuan Guru Kelas Siklus 2

\begin{tabular}{|c|c|c|c|c|}
\hline \multirow{2}{*}{ No } & Nama Guru & \multicolumn{3}{|c|}{ Skor Penilaian } \\
\cline { 3 - 5 } & & $\begin{array}{c}\text { Persiapan } \\
\text { Penyusunan RPP }\end{array}$ & $\begin{array}{c}\text { Aktivitas Guru Dalam } \\
\text { Proses Pembelajaran }\end{array}$ & $\begin{array}{c}\text { Penilaian } \\
\text { RPP }\end{array}$ \\
\hline 1 & A & 7 & 35 & 147 \\
\hline 2 & B & 9 & 37 & 155 \\
\hline & Jumlah & 16 & 72 & 302 \\
\hline & Rata-rata & 8 & 36 & 151 \\
\hline
\end{tabular}

Penilaian melalui rubrik penilaian rencana pelaksanaan pembelajaran pada siklus 2 yang mencapai nilai 151, berada pada katagori sangat baik, dan (b) aktivitas guru dalam pelaksanaan pemebelajaran pada siklus 2 lebih baik daripada pada saat siklus 1. Penilaian melalui Rubrik Penilaian Aktivitas Guru dalam proses pembelajaran selama pada siklus kedua mencapai nilai 36, yang berarti tergolong sangat baik.

Berdasarkan hasil observasi pelaksanaan tindakan kedua, ditemukan bahwa: Guru mencantumkan komponen identitas dengan segala rinciannya dengan benar.

1) Guru mencantumkan standar kompetensi (SK) yang sesuai dengan standar isi dan silabus.

2) Guru mencantumkan kompetensi dasar (KD) yang sesuai dengan standar isi dan silabus.

3) Guru mencantumkan komponen Indikator Pencapaian dengan rumusan kalimat yang mengandung kata kerja operasional yang terukur sebagai penjabaran kompetensi dasar, dan sesuai dengan materi pembelajaran. 
4) Guru mencantumkan komponen Tujuan Pembelajaran dengan kalimat yang mencantumkan subyek belajar (learner), target yang dicapai siswa, dan relevan dengan kompetensi dasar (KD)

5) Guru mencantumkan komponen Materi Pembelajaran dengan rincian yang sistematis, sesuai dengan tujuan pembelajaran (TP) dan standar isi, dan telah mencantumkan materi pembelajaran untuk pengayaan.

6) Guru mencantumkan komponen Kegiatan Pembelajaran, membaginya kedalam Kegiatan Pembelajaran Pendahuluan, Kegiatan Pembelajaran Inti dan Kegiatan Pembelajaran Penutup. Setiap bagian dirinci menjadi kegiatan pembelajaran yang student centered, disertai alokasi waktu tiap kegiatan siswa.

7) Guru mencantumkan komponen Metoda /Model Pembelajaran yang disatukan secara sistematis dengan komponen Kegiatan Pembelajaran.

8) Guru dapat mencantumkan komponen Media/Sumber Pembelajaran dengan menentukan jenis sumber belajarnya sesuai dengan tuntutan kurikulum (kompetensi dasar dan silabus), tujuan pembelajaran, dan bentuk evaluasi.

9) Guru mencantumkan komponen Penilaian (Evaluasi) Proses dan Hasil Pembelajaran, dan merincinya dengan lengkap, dari mulai bentuk evaluasi, menyertakan lembaran/format instrumen penilaian (butir soal, rubrik, dll.), pedoman penilaian, dan kunci jawabannya.

10) Hasil observasi melalui Rubrik Penilaian Rencana Pelaksanaan Pembelajaran (RPP), nilainya mencapai nilai 151, yang berarti berada pada katagori sangat baik.

11) Hasil observasi melalui Rubrik Penilaian Aktivitas Guru dalam Menyusun Rencana Pelaksanaan Pembelajaran (RPP) selama Kegiatan Supervisi, nilainya mencapai nilai 36, yang berati berada pada katagori sangat baik. 


\section{E. KESIMPULAN DAN SARAN}

\section{Kesimpulan}

Kesimpulan dari hasil penelitian yang peneliti sajikan dalam Penelitian Tindakan Sekolah (PTS) ini adalah sebagai berikut:

1. Pembinaan berkelanjutan melalui supervisi akademik dapat meningkatkan kemampuan guru dalam melaksanakan Proses Pembelajaran dengan menggunakan Teknologi, Informatika dan Komunikasi. Hal ini dapat diketahui dalam hasil penelitian dari jumlah skor kondisi awal 155 menjadi 195. Jadi peningkatannya sebesar $25,8 \%$.

2. Pembinaan berkelanjutan dapat meningkatkan motivasi guru dalam menyusun perencanaan pembelajaran dengan menggunakan TIK.

\section{Saran}

Berdasarkan hasil penelitian di atas, maka saran yang dapat disampaikan diantaranya:

1. Kompetensi guru menerapkan TIK dalam proses pembelajaran perlu mendapatkan perhatian penuh dari kepala sekolah atau pun pengawas..

2. Kepada guru diharapkan selalu mengikuti perkembangan jaman, sehingga tidak ketinggalan dengan yang lain.

\section{DAFTAR PUSTAKA}

Abdul Hadis dan Nurhayati, Manajemen Mutu Pendidikan, Bandung: Alfabeta, 2012.

Abdulhak, Ishak dan Deni Darmawan, Teknologi Pendidikan, Bandung : PT Remaja Rosdakarya, 2013.

Bambang Warsita, Teknologi Pembelajaran: Landasan \&Aplikasinya, Jakarta: Rineka Cipta, 2008.

E. Mulyasa, Standar Kompetensi dan Sertifikasi Guru, Bandung: PT Remaja Rosdakarya, 2013.

Hamzah B. Uno, Nina Lamatenggo, Teknologi. Komunikasi dan Informasi Pembelajaran. Jakarta: Bumi Aksara, 2011. 
Imam Wahyudi, Panduan Lengkap Uji Sertifikasi Guru, (Jakarta: PT. Prestasi Pustakarya, 2012.

Jamil Suprihatiningkrum, Guru Profesional : Pedoman Kinerja, Kualifikasi \& Kompetensi Guru, Yogyakarta: Ar-Ruzz Media, 2014.

Jejen Musfah, Peningkatan Kompetensi Guru : Melalaui Pelatihan dan Sumber Belajar Teori dan Praktik, Jakarta: Kencana, 2012.

Marselus R.Payong, Sertifikasi Profesi Guru: Konsep Dasar, Problematika dan Implementasinya, Jakarta: PT.Indeks, 2011.

Mukhtar dan Iskandar, Orientasi Baru Supervisi Pendidikan, Jakarta: Gaung Persada Press, 2009.

Nasution. Teknologi Pendidikan. Jakarta: Bumi Aksara, 2011.

Ngalim Purwanto, Administrasi dan Supervisi Pendidikan, Bandung: PT Remaja Rosadakarya, 2005.

Piet A. Sahertian, Konsep Dasar dan Tekhnik Supervisi Pendidikan dalam Rangka Pengembangan Sumber Daya Manusia, Jakarta: PT Rineka Cipta, 2000.

Rusman dkk, Pembelajaran Berbasis Teknologi Informasi dan Komunikasi . Jakarta : Grafindo Persada, 2012.

Suyanto dan Asep Jihad, Menjadi Guru Profesional: Strategi Meningkatkan Kualifikasi dan Kualitas Guru di Era Globalisasi, Jakarta: Erlangga, 2013.

Rika Ariyani, Editor Jurnal Literasiologi. Literasi Kita Indonesia. STAI Syekh Maulana Qori. 